\title{
Keberhasilan Tindakan Resusitasi Jantung Paru dan Otak Terhadap Pasien Gagal Jantung Kongestif di Rumah Sakit Umum Universitas Kristen Indonesia
}

\author{
$\underline{\text { Ratna Emelia Hutapea }}^{1}$, Josua Louis Farry Mundung ${ }^{2}$ \\ ${ }^{1}$ Departemen Anestesiologi Rumah Sakit Umum Universitas Kristen Indonesia, Jakarta \\ ${ }^{2}$ Fakultas Kedokteran Universitas Kristen Indonesia, Jakarta \\ Email: ratnamelial@gmail.com
}

\begin{abstract}
ABSTRAK : Gagal jantung kongestif adalah suatu ketidak mampuan jantung untuk memompa darah keseluruh tubuh yang dapat menyebabkan kematian. Banyaknya angka kematian diakibatkan gagal jantung menjadikan perlunya penanganan segera pada seseorang yang mengalami gagal jantung. Resusitasi Jantung Paru dan Otak (RJPO) merupakan bantuan awal korban henti jantung. Penelitian ini dilakukan untuk mengetahui gambaran tingkat keberhasilan resusitasi jantung paru dan otak terhadap pasien gagal jantung kongestif di Rumah Sakit Umum Universitas Kristen Indonesia. Metode analisis yang digunakan adalah univariat secara retrospektif pada 45 pasien dengan rekam medis di RSU UKI pada periode 2015-2017. Hasil penelitian menyatakan bahwa, dari 45 pasien berdasarkan jenis kelamin, pasien perempuan mempunyai tingkat keberhasilan resusitasi sebesar 13,3\% dan laki-laki 10\%. Keberhasilan berdasarkan usia, 21-40 tahun 0\%, 41-60 tahun 5,2\%, 61-80 tahun 17,4\%, dan usia 81-100 tahun 0\%. Berdasarkan tempat dilakukan resusitasi, tingkat keberhasilan di bangsal 0\%, UGD 14,8\%, dan ICU 6,2\%. Berdasarkan pemberian adrenalin, tingkat keberhasilan pasien yang diberikan adrenalin 14,7\% dan yang tidak diberikan adrenalin 0\%. Dari hasil penelitian dapat disimpulakan bahwa tingkat keberhasilan resusitasi terbesar adalah Perempuan, usia 61-80 tahun, dilakukan di UGD, dan diberikan Adrenalin.
\end{abstract}

\section{Kata kunci : Keberhasilan, RJPO, Gagal Jantung Kongestif}

ABSTRACT : Congestive heart failure is an inability of the heart to pump blood around the body which can cause death. The large number of deaths due to heart failure makes the need for immediate treatment for someone who has heart failure Cardiac and Brain Resuscitation is an initial aid for victims of cardiac arrest. This study was conducted to describe the success rate of cardiac and brain resuscitation in patients with congestive heart failure at the General Hospital of the Christian University of Indonesia. The analytical method used was univariate retrospectively in 45 patients with medical records at the UKI Hospital in the 2015-2017 period. The results of the study stated that, out of 45 patients based on gender, female patients had a successful resuscitation rate of $13.3 \%$ and male patients 10\%. Success Based on Age, 21-40 years 0\%, 41-60 years 5.2\%, 61-80 years $17.4 \%$, and ages 81-100 years $0 \%$. Based on the place where resuscitation was performed, the success rate in wards was $0 \%$, emergency room $14.8 \%$, and ICU was $6.2 \%$. Based on adrenaline administration, the success rate for patients who were given adrenaline was $14.7 \%$ and those who were not given adrenaline were $0 \%$. From the results of the study it can be concluded that the greatest success rate of resuscitation is women, aged 61-80 years, performed in the emergency room, and given Adrenaline.

Keywords : Success, RJPO, Congestive Heart Failure 


\section{PENDAHULUAN}

Gagal jantung kongestif adalah suatu ketidak mampuan jantung untuk memompa darah ke seluruh tubuh yang dapat menyebabkan kematian. Prevalensi gagal jantung di Indonesia sebesar $0,13 \%$ atau sekitar 229.696 orang (1), dengan tingkat kematian akibat gagal jantung terjadi pada $50 \%$ kasus dalam kurun waktu lima tahun setelah terdiagnosis.

Banyaknya angka kematian yang diakibatkan oleh penyakit gagal jantung, maka perlu dilakukan penangan dengan segera ketika seseorang mengalami gagal jantung akut dimana hal tersebut dapat berujung pada kondisi henti jantung (cardiac arrest).Bantuan Hidup Dasar dalam hal ini yaitu tindakan Resusitasi Jantung Paru dan Otak (RJPO).

Rumah Sakit Umum Universitas Kristen Indonesia (UKI) adalah RSU yang telah beroperasi 59 tahun. Rumah Sakit Umum UKI telah menangani banyak pasien gagal jantung. Berdasarkan hasil penelitian dari Afnan yang berjudul Profil pasien Gagal Jantung Kongestif di Rumah Sakit Umum UKI periode Januari 2017-September 2018 didapatkan kesimpulan bahwa dari 77 sampel pasien Gagal jantung Kongestif angka kejadian gagal jantung tertinggi adalah pada usia diatas 65 tahun dengan riwayat keluarga menderita penyakit Kardiovaskular paling banyak. ${ }^{(2)}$

Berdasarkan masalah diatas, penulis tertarik untuk melakukan penelitian dengan judul “Gambaran tingkat keberhasilan tindakan resusitasi jantung paru dan otak terhadap kasus gagal jantung kongestif di Rumah Sakit Umum Universitas Kristen

Indonesia". Tujuan dengan adanya penelitian ini adalah untuk mengetahui efektivitas resusitasi jantung paru dan otak terhadap kasus gagal jantung kongestif di Rumah Sakit Umum Universitas Kristen Indonesia periode 2015-2017.

Menurut Kasper dkk Gagal jantung kongestif adalah adalah keadaan dimana jantung tidak mampu memompa darah untuk mencukupi kebutuhan jaringan melakukan metabolism. ${ }^{(3)}$ Gejala khas pasien gagal jantung yaitu: sesak nafas saat istirahat atau beraktivitas, kelelahan dan edema tungkai, sedangkan tanda khas gagal jantung adalah takikardi, takipnea, suara ronki, efusi pleura, peningkatan vena jugularis, edema perifer dan hepatomegali. ${ }^{(4)}$

Bantuan Hidup Dasar pasien gagal jantung yaitu tindakan Resusitasi Jantung Paru dan Otak (RJPO). RJPO adalah suatu tindakan pertolongan yang dilakukan kepada korban yang mengalami henti nafas dan henti jantung termasuk akibat gagal jantung dengan teknik penekanan dada dan ventilasi buatan untuk menjaga aliran peredaran darah dan oksigenasi. $^{(5)}$ Tindakan RJPO terdiri dari beberapa tahapan yaitu circulation, Airway, Breathing, dan Defibrilasi. ${ }^{(6)}$

\section{METODOLOGI PENELITIAN}

Penelitian ini menggunakan desain penelitian deskriptif retrospektif dengan menggunakan data sekunder dari rekam medik pasien untuk melihat tingkat keberhasilan resusitasi jantung paru dan otak terhadap pasien gagal jantung kongestif di Rumah Sakit Umum Universitas Kristen Indonesia pada periode 2015-2017. Populasi pada penelitian ini adalah pasien gagal jantung kongestif yang mendapatkan tindakan medis berupa resusitasi jantung paru dan otak. Total populasi yang 
digunakan sesuai dengan rekam medis Rumah Sakit Umum Universitas Kristen Indonesia periode 2015-2017. Pemilihan besar Sampel penelitian ini dengan menggunakan metode total sampling, yaitu jumlah populasi yang ada sama dengan jumlah sampel. Setelah melalui proses eksklusi dan inklusi didapatkan jumlah sampel sebanyak 45 sampel.

Analisis data pada penelitian ini adalah analisis univariat dilakukan untuk melihat frekuensi pada setiap variabel serta melihat gambaran distribusi homogenitas dari 45 pasien. Analisis univariat bertujuan untuk menjelaskan atau mendeskripsikan karakteristik setiap variabel penelitian dengan membuat tabel distribusi frekuensi. Adapun faktor- faktor inklusi yang dipilih adalah jenis kelamin, usia (21-40; 41-60; 6180; 81-100), tempat (bangsal; UGD; ICU), dan penggunaan adrenalin pada pasien gagal jantung kongestif yang diresusitasi.

\section{HASIL DAN PEMBAHASAN PENELITIAN}

Dari hasil penelitian berdasarkan Tabel 1. terdapat 45 pasien yang didiagnosis menderita penyakit gagal jantung kongestif dan menerima tindakan RJPO di Rumah Sakit Umum Universitas Kristen Indonesia, terdiri dari 15 perempuan $(33,3 \%)$ dan 30 laki - laki (66,7\%). Terdapat 2 pasien berusia 21 - 40 tahun $(4,4 \%), 19$ pasien berusia 41 - 60 tahun $(42,2 \%), 23$ pasien berusia 61 - 80 tahun $(51,5 \%)$, dan 1 pasien berusia $81-100$ tahun $(2,2 \%)$.

Tabel 1 : Distribusi Frekuensi Pasien Berdasarkan Karakter Pasien yang Diberikan Tindakan Resusitasi Jantung Paru dan Otak

\begin{tabular}{llll}
\hline Faktor & Data $(\%)$ & Berhasil (\%) & Gagal (\%) \\
\hline Jenis Kelamin & & & \\
Perempuan & $15(33,3 \%)$ & $2(13,3 \%)$ & $13(86,7 \%)$ \\
Laki-laki & $30(66,7 \%)$ & $3(10 \%)$ & $27(90 \%)$ \\
Usia & & & \\
$21-40$ & $2(4,4 \%)$ & $0(0 \%)$ & $2(100 \%)$ \\
$41-60$ & $19(42,2 \%)$ & $1(5,2 \%)$ & $18(94,8 \%)$ \\
$61-80$ & $23(51,1 \%)$ & $4(17,4 \%)$ & $19(82,6 \%)$ \\
$81-100$ & $1(2,2 \%)$ & $0(0 \%)$ & $1(100 \%)$ \\
Tempat & & & $2(100 \%)$ \\
Bangsal & $2(4,4 \%)$ & $0(0 \%)$ & $23(85,2 \%)$ \\
UGD & $27(60 \%)$ & $4(14,8 \%)$ & $15(93,8 \%)$ \\
ICU & $16(35,6 \%)$ & $1(6,2 \%)$ & \\
Adrenalin & & & $29(85,3 \%)$ \\
Ya & $34(75,6 \%)$ & $5(14,7 \%)$ & $11(100 \%)$ \\
Tidak & $11(24,4 \%)$ & $0(0 \%)$ & $40(88,9 \%)$ \\
\hline Total & $45(100 \%)$ & $5(11,1 \%)$ & \\
\hline
\end{tabular}


Berdasarkan jenis kelamin, terdapat 5 pasien yang tertolong setelah diberikan RJPO yaitu 3 pasien laki - laki dan 2 pasien perempuan. Hal ini didukung dengan hasil penelitian dari Rory Hamza di RS PKU Muhammadiyah Yogyakarta yang menyatakan bahwa penyakit gagal jantung kongestif lebih banyak ditemukan pada laki-laki dibandingkan perempuan. Selain itu hasil penelitian dari Arif Nur Akhmad di RSUP Dr. Sardjito Yogyakarta juga menyimpulkan bahwa $71 \%$ pasien gagal jantung kongestif berjenis kelamin laki-laki. ${ }^{(7)}$ Hasil penelitian dari Putri juga menunjukkan bahwa banyaknya pasien gagal jantung di RSUD Dr. Moewardi Surakarta sebagian besar berjenis kelamin Laki-laki. ${ }^{(8)}$ Didapatkan juga hasil penelitian Rita Sekarsari di poli jantung RS Tangerang yang menyatakan bahwa penyakit gagal jantung kongestif didominasi oleh usia 66-85 tahun sebanyak 16 orang $(53,3 \%)$ dibandingkan dengan kelompok usia 45-65 tahun sebanyak $(46,7 \%)$ dan pada penelitian tersebut penyakit jantung kongestif lebih banyak ditemukan pada laki laki sebanyak 17 orang $(56,7 \%)$ dibandingkan pada perempuan sebanyak 13 orang $(43,3 \%) .{ }^{(9)}$

Berdasarkan hasil penelitian, pasien gagal jantung kongestif yang berhasil hidup setelah diberikan tindakan resusitasi berjumlah 5 pasien $(11,1 \%)$, sedangkan jumlah pasien yang meniggal setelah mendapatkan tindakan resusitasi sebanyak 40 pasien $(88,9 \%)$. Hal ini didukung oleh penelitian Andri Cahyono di RS Wava Husada tahun 2015, bahwa dari total 14 responden, $92,8 \%$ responden yang melakukan tidakan RJPO dengan tepat dan dari $92.8 \%$ responden yang melakukan RJPO dengan tepat, terdapat $57.1 \%$ tidak berhasil mengembalikan nadi pasien dan $35.7 \%$ berhasil mengembalikan nadi pasien. ${ }^{(10)}$

Dari hasil penelitian ini didapatkan bahwa, dari 45 pasien yang mengalami gagal jantung kongestif dan mendapatkan tindakan resusitasi jantung paru, didapatkan tingkat keberhasilan resusitasi yang lebih besar pada pasien dengan jenis kelamin laki-laki berusia 61-80 tahun. Resusitasi yang dilakukan di UGD memiliki tingkat keberhasilan yang lebih besar dibandingkan dengan resusitasi yang dilakukan di bangsal ataupun ICU. Resusitasi yang dilakukan disertai dengan pemberian adrenalin juga memiliki tingkat keberhasilan yang lebih besar dibandingkan dengan resusitasi yang tidak disertai dengan pemberian adrenalin. Hasil penelitian ini didukung oleh penelitian dari Asep Suryana yang menyatakan bahwa kehadiran adrenalin akan meningkatkan volum curah jantung sehingga jumlah darah yang dialirkan oleh jantung ke seluruh tubuh akan meningkat. ${ }^{(11)}$ Hasil penelitian dari Putra dan Nani menyatakan bahwa untuk pencegahan primer terjadinya henti jantung pada atlet di lapangan permainan yang disebabkan oleh masalah jantung direkomendasikan melakukan PreParticipating Evaluation (PPE) dimana salah satunya adalah bantuan hidup lanjut berupa pemberian obat adrenalin atau Epinefrin. ${ }^{(12)}$

\section{KESIMPULAN}

Pasien yang mengalami gagal jantung kongestif di RSU UKI umumnya 
berjenis kelamin laki-laki, dan pasien berjenis kelamin laki-laki juga ditemukan lebih banyak mendapatkan tindakan resusitasi dibandingkan pasien dengan jenis kelamin perempuan. Pasien gagal jantung kongestif yang berhasil hidup setelah diberikan tindakan resusitasi berjumlah 5 pasien $(11,1 \%)$, sedangkan jumlah pasien yang meninggal setelah mendapatkan tindakan resusitasi sebanyak 40 pasien (88,9\%). Diharapkan pada penelitian selanjutnya dapat dilakukan uji ulang tentang Keberhasilan Tindakan Resusitasi Jantung Paru dan Otak Terhadap Pasien Gagal Jantung Kongestif dengan menggunakan sampel yang lebih banyak dengan waktu penelitian yang lebih lama.

\section{DAFTAR PUSTAKA}

1. Department Kesehatan Republik Indonesia. Riset Kesehatan Dasar Tahun 2013. Diunduh dari http://www.depkes.go.id/resources/downl oad/general/Hasil\%20Riskesdas\%202013 . 15 September 2017.

2. Afnan. Profil Pasien Gagal Jantung Kongestif di Rumah Umum UKI Periode Januari 2017-September 2018 [Skripsi]. Jakarta:Universitas Kristen Indonesia. 2018.

3. Kasper DL, Hauser SL, Jameson JL, Fauci AS, Longo DL, et all. Harrison's Principles of Internal Medicine. $19^{\text {th }}$ Edition. United States: McGraw-Hill Companies, 2015.

4. Siswanto BD, Hersunati N, Erwinanto,
Barrack R, Pratikto RS, et all. Pedoman Tatalaksana Gagal Jantung. Diunduh dari http://www.inaheart.org/upload/file/Pedo man_TataLaksana_Gagal_Jantung_2015. pdf. 13September 2017.

5. Subagjo A, Achyar, Ratnaningsih E, Sugiman T, Kosasih A, et all. Bantuan Hidup Jantung Dasar. Jakarta: PP PERKI, 2011.

6. American Heart Association. Guidelines CPR and ECC. USA: AHA, 2015.

7. Arif NA, Yanuar P, Yuni PI. Kualitas Hidup Pasien Gagal Jantung Kongestif Berdasarkan Karakteristik Demografi. 2016;11(1).

8. Putri CM. Gambaran Tipe Kepribadian Pada Pasien Gagal Jantung Kongestif di RSUD Dr. Moewardi Surakarta [Skripsi]. Surakarta: Universitas Muhammadiyah Surakarta. 2018.

9. Sekarsari R, Suryani AI. Gambaran Aktivitas Sehari-hari pada pasien gagal jantung kelas II dan III di Poli Jantung RSU Kabupaten Tangerang. Jurnal JKFT. 2017 Mar 3;1(2):1-7.

10. Cahyono A. Ketepatan Posisi Penolong Saat Resusitasi Jantung Paru Terhadap Keberhasilan Resusitasi Jantung Paru (Studi Pada Pasien Cardiac Arrest Di RS Wava Husada) (Doctoral dissertation, University of Muhammadiyah Malang).

11. Asep Suryana A. Efek Adrenalin Terhadap Kerja Jantung. 2015;10(1).

12. Putra Rizky, Nani C. Tata Laksana Henti Jantung di Lapangan Permainan. 2017;13(2). 